\title{
Selection of Industrial Trade Waste Resource Recovery Technologies-A Systematic Review
}

\author{
Jake A. K. Elliott*(D) and Andrew S. Ball ${ }^{(D)}$
}

check for updates

Citation: Elliott, J.A.K.; Ball, A.S. Selection of Industrial Trade Waste Resource Recovery Technologies-A Systematic Review. Resources 2021, 10, 29. https://doi.org/10.3390/ resources 10040029

Academic Editors: Daniel Puyol and Angel Fernández Mohedano

Received: 29 January 2021

Accepted: 26 March 2021

Published: 29 March 2021

Publisher's Note: MDPI stays neutral with regard to jurisdictional claims in published maps and institutional affiliations.

Copyright: (c) 2021 by the authors. Licensee MDPI, Basel, Switzerland. This article is an open access article distributed under the terms and conditions of the Creative Commons Attribution (CC BY) license (https:/ / creativecommons.org/licenses/by/ $4.0 /)$.
ARC Training Centre for the Transformation of Australia's Biosolids Resource, RMIT University, Bundoora 3083, Australia; andy.ball@rmit.edu.au

* Correspondence: s3511122@student.rmit.edu.au

\begin{abstract}
Industrial wastewater and other trade wastes are often sources of pollution which can cause environmental damage. However, resource recovery approaches have the potential to lead to positive environmental outcomes, profits, and new sources of finite commodities. Information on these waste sources, and the valuable components which may be contained in such waste is increasingly being made available by public, academic and commercial stakeholders (including companies active in meat processing, dairy, brewing, textile and other sectors). Utilising academic and industry literature, this review evaluates several methods of resource recovery (e.g., bioreactors, membrane technologies, and traditional chemical processes) and their advantages and disadvantages in a trade waste setting. This review lays the groundwork for classification of waste and resource recovery technologies, in order to inform process choices, which may lead to wider commercial application of these technologies. Although each waste source and recovery process is unique, membrane bioreactors show promise for a wide range of resource recovery applications. Despite interest, uptake of resource recovery technologies remains low, or not widely championed. For this to change, knowledge needs to increase in several key areas including: availabilities and classification of trade wastes, technology choice processes, and industrial viability.
\end{abstract}

Keywords: resource recovery; trade waste; industrial wastewater; biogas; struvite; membrane

\section{Introduction}

Trade waste, or trade effluent, is liquid waste put into the sewer system from a commercial or industrial premises [1]. Over the last century, pollution from industrial trade wastes have been understood as destructive [2], with eutrophication of waterways [3], the spread of disease [4], odours [5], aesthetic decline [2], and damage to infrastructure [6] all linked to poorly treated waste. Despite these large costs to the environment, dumping of untreated waste has previously been a relatively normalised operation, often with no direct cost to the polluter. However, due to recognition of the environmental impact of pollution, government agencies providing water and sewerage services have developed and imposed a series of limitations on the concentrations and daily amounts of certain components in trade waste released to sewer [7]. Expensive treatment must often be undertaken by the trade waste customer (TWC) to bring waste parameters within these limits before discharge.

The need to meet requirements established by environmental laws and the increased costs of those treatments can lead producers to evaluate the potential benefits of resource recovery on industrial wastewaters. Life cycle analyses have shown that utilising resource recovery techniques has the potential to lead to positive environmental outcomes, profits, and new sources of finite commodities [8]. The most common resource recovered from wastewater is the water itself, for reuse in the plant; it would otherwise be disposed of [9]. Depending on the industry, other recoverable resources include nutrients for fertiliser [10], energy for heating and electricity production [11], metals [2], and reagents [12]. In a world 
where greenhouse gas emissions, water scarcity, famine, and resource shortages present an ever-increasing danger to our continued life, recovery of resources from trade wastes can go some way to closing the loop in the circular economy, while providing a profit stream, reducing waste fees, improving a company's green credentials, and potentially minimising environmental damage. Informed choices must be made, however, as resource recovery is not a guaranteed panacea for environmental impacts, and may in fact increase certain emissions [13].

Industry currently brings trade waste into specification through the application of a number of protocols, depending on the properties of the waste stream. Acid and caustic can be dosed to achieve prescribed $\mathrm{pH}$ levels, settling tanks and screens can remove oil and large solids, and dissolved air flotation (DAF) units can separate some suspended and dissolved components [10].

The first class of resource recovery process investigated in this review are extensions and refocusing of these basic techniques from removal and disposal to recovery and reuse. Valuable chemicals, like struvite (used as a fertiliser), can be produced by modifying conditions and achieving stoichiometric ratios. Operating parameters and additives for physical separation treatments like DAF can be optimised, with resources being recovered, instead of being sent to landfill.

Physical separation can also be achieved through membranes. More advanced than simple screens, membrane technology has advanced significantly in recent decades [14]. Plastics chemistry and manufacturing techniques have opened possibilities in selectivity and flux, utilizing temperature, pressure, and concentration gradient driving forces. Membrane modules can be used individually, or in combination with other membranes or processes [14]. An important combination is the membrane bioreactor (MBR), which combines controlled biological processes with separation technology. This allows an MBR to decouple the solid and hydraulic retention times [15] so mature sludge can be held in the reactor, while fermentation liquor can be removed, increasing efficiency. MBR is suitable for both aerobic and anaerobic operations, showing promise for biogas generation.

Microbial fuel cells (MFC) are another nascent technology for recovering energy from liquid wastes. Despite still being in development, there is promise in using microbial reactors for electricity generation $[16,17]$.

Although it is to be removed before discharge to sewer, fat, oil, and grease (FOG) in wastewater is an interesting resource. Energy rich, it can be used in the production of biodiesel, or in fry-drying of other fuel-from-waste products [18].

The final component to be discussed in this review is heat. Direct use or conversion of thermal energy from gaseous exhausts is widely studied in industry, but recouping heat from wastewater is less known $[19,20]$.

The academic literature surrounding actual plant-scale resource recovery is limited; however case studies are available, particularly those processes which are being commercialised [12,21,22].

Currently in the literature, there is a shortage of reviews around the technologies and decision processes in resource recovery for industrial trade waste customers. Existing reviews of resource recovery technology and programmes $[9,23]$ are frequently centred around municipal wastewater, including residential sewage, meaning that these findings are unlikely to be directly translatable to trade wastes, which tend to have unique characteristics. Available reviews on industrial water treatment [24] tend to focus more on zero-liquid-discharge and preventing waste.

This study aims to evaluate the possibilities for industrial integration of resource recovery from trade wastes, classification of waste streams and understanding of the technologies available, as there are no current reviews available on this confluence of topics. This review will look at processes with widespread applications to appeal to the broadest audience, and avoid instances of recovery of niche products, research of which is more suitable for individual businesses. 


\section{Materials and Methods}

\subsection{Scope of Review}

This review investigates the major factors behind decision-making in trade waste resource recovery. Firstly, classification schemes and chemical components of interest in trade wastes, namely those aspects determining the desirability of recovering components, e.g., reclaimable value, recoverable quantity of a resource, and the likelihood of municipal water treatment providers enacting discharge limitations for a given parameter. Secondly, trade waste resource recovery technologies, including current applications in industry, as well as future opportunities to use novel methods to extract economic value and mitigate environmental damage from trade waste streams.

The aim of this investigation is to understand the state of the art and identify future development options, through critically reviewing resource recovery applications. To the best of the authors' knowledge, there is not a current compilation of identification techniques and resource recovery technologies for industrial trade wastes. Any review found, both using the methodology outlined below, and specific searches for reviews, was either outdated, specifically about one technology, or not about industrial wastewater or trade wastes. This review aims to fill this literature gap, while identifying areas for further study.

\subsection{Review Methodology Design}

Examples of the commercial application of resource recovery technologies are vital for decision making in industry and understanding the potential practical applications. Therefore, as part of this study, grey literature was deemed valid for inclusion, along with peer-reviewed, academic literature.

Studies of residential and municipal wastewater resources are not directly applicable to the individual industrial trade waste field, due to differences in waste components and centralisation of treatment. However, this literature was utilised as launching points for identifying procedures that had potential in the trade waste resource recovery field.

Recovery or production of niche, specialty components is limited to a relatively narrow range of cases, so was only used as supporting evidence for technologies with a wider extent of recoverable resources. Recovery of unique high-value chemicals is more likely to be within the scope of commercial research, driven by the presence of the individual component in a waste stream, and therefore not covered by the scope of this review.

\subsection{Literature Search Methodology}

Initial searches of "trade waste" AND "resource recovery" were made through RMIT University LibrarySearch for an overview of topics in the field. This database search included journal articles, news items, books, and dissertations. Further searches were also undertaken on LibrarySearch, Google Scholar and Scopus, using similar terms and combinations of individual technologies (e.g., "membrane distillation"), industries (e.g., "dairy"), and waste resource components (e.g., "FOG") as search terms.

Checking references of appropriate papers (snowballing) and finding articles that cited useful research (reverse-snowballing) expanded the range of literature found. As these techniques and search engines were generally limited to academic literature, individual Google searches were then used to source practical and commercial applications, as well as to identify and consider any regulatory issues. By definition, these searches resulted in "grey literature" being included, but were necessary for finding real world applications and examples of industrial uptake. Initial searches began in May 2020, with further searches and refinements made until March 2021. No date ranges were enforced during searches, as this could exclude key information, particularly around trade waste contents and their effects, and commonly used water treatment techniques. These trends change far more slowly, if at all, but are integral as a basis to future work. Scanning literature highlighted the trade waste sources of the brewing, dairy, edible oil, meat, and textile industries, the technologies including biological, chemical and bioelectrochemical reactions, membranes, 
and heat capture, and the final products of fuels and fertilisers. While searching academic literature, Scimago journal rankings [25] were used to assess the quality of paper. Over $85 \%$ of the journal articles cited were published in quartile 1 (Q1) journals, as can be seen in Figure 1. A small number of other resources, including manufacturer case studies, were also included, and effort was made to favour reputable sources such as municipal service providers and industry groups.

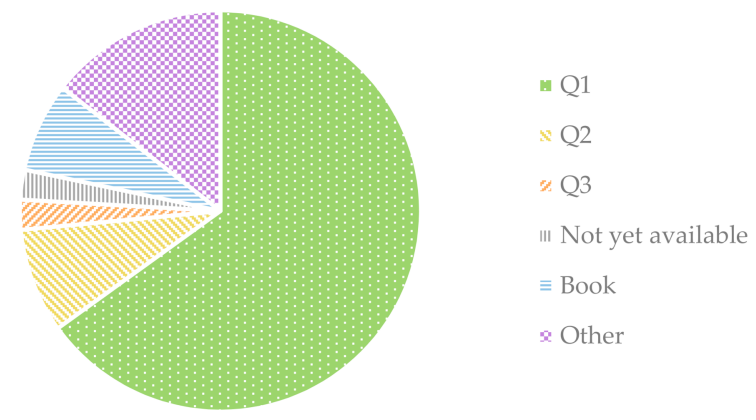

Figure 1. Citation source breakdown. Fifty four of the 63 journal articles cited were published in Q1 journals, as per Scimago Journal Rankings [25]. No articles from Q4 journals were cited in the final version of this review. Excluding Scimago itself, 18 citations of books and other sources are made.

Many hundreds of sources were found using this methodology. This list was narrowed down manually to 298 documents by evaluating titles and abstracts, before the final list of citations was populated. 63 peer reviewed papers were selected for citation in this review.

Finally, information was categorised manually into two broad sections: (i) contents of interest in trade wastes, and (ii) the methods to recover them. This information was compared, evaluated and compiled into the review, with each section culminating in the synthesis of tables summarising trade waste components and resource recovery technologies, respectively.

\section{Results}

\subsection{Sources and Characteristics of Trade Waste}

Trade waste customers can include large facilities such as meat processing plants, hydrocarbon refineries, and textile manufacturers, through to individual restaurants and smaller-scale manufacturers. As such, trade waste originating from these diverse sources will in turn display different compositional profiles, depending on the industry, plant, and even production run. Some major properties of interest are $\mathrm{pH}$, salinity, nutrients, chemical oxygen demand (COD), biological oxygen demand (BOD), FOG, and chemicals that make treatment processes difficult.

Cleaning products tend to have a large impact on $\mathrm{pH}$ values of wastewaters, especially in dairy operations [5]. Durham and Hourigan [26] identified acidic and caustic cleaning chemicals as potential component streams in dairy trade waste, in addition to washdown from milk receipt and by-products from cheese whey production. Overall, dairy waste has relatively high organic loading, nitrogen, and phosphorus, but cheese processing effluent has particularly high salinity [27].

Another high-sodium waste is produced by the meat processing plant internal stream known as "green waste". Green waste is mainly wash water and organ processing effluent, and contains high concentrations of phosphorus and sodium, as well as some organic load [28]. It is this waste stream that draws most parallels to domestic waste, unlocking a wider field of research. Red waste, from slaughter and carcass processing, contains high levels of nitrogen from protein, and FOG [29].

FOG levels may also be as high as $6.5 \mathrm{~g} / \mathrm{L}$ in olive oil mill effluent [30], a level indicative of most edible oil refining wastes. This loss of product can mostly be caused by leaks and cleaning, and results in high BOD [4]. By definition, any process losing edible oil to sewer will produce trade waste with a FOG content. This is particularly significant in 
retail restaurant and food service establishments and prepared meal production processes using frying.

In large-scale food manufacturing facilities, organic waste may be generated by spillage, cleaning processes, and when the production line switches from one item to another. Other contents depend on food produced, but food manufacturing waste will generally have low nitrogen and phosphorus [4]. Process choices can impact the level of waste. Frying food will result in higher FOG levels, and cleaning floors by hosing down flour into drains instead of sweeping into bins will increase COD. Process changes which increase water efficiency can result in wastewater that is lower volume, but more highly concentrated [31].

High COD wastewater with low phosphate and nitrogen is also common in grain malting for beverage production [4]. This is notable as being complementary to major components in meat processing. In the brewing and distillation process, each step's waste is unique, and some are at high temperatures, which could prove valuable as a source of recoverable heat. Overall, waste volumes are 4.5 times that of the saleable beer volume [32], indicating a potentially vast source for resource recovery.

Fruit and vegetable processing wastes, including that of juice production, can have a wide range of deleterious components, including pesticides, cleaning compounds, and waxes [4], meaning biological treatment processes may not be suitable. Technology that can withstand dairy and food manufacturing CIP effluent may be transferable to these wastes.

Table 1 shows a selection of measured properties of trade waste from literature. Although a process in an individual location or business may have unique characteristics, Table 1 indicates wider trends in each industry. Further research is required into the variability of these trends. Understanding the consistency of these values could help in identifying which treatment technologies can be transferred between industries. 
Table 1. Example components of trade waste by industry

\begin{tabular}{|c|c|c|c|c|c|c|c|c|c|c|c|c|}
\hline & Cheese Whey & $\begin{array}{c}\text { Dairy } \\
\text { Processing }\end{array}$ & $\begin{array}{c}\text { Whey } \\
\text { Wastewater }\end{array}$ & $\begin{array}{c}\text { Red Meat } \\
\text { (High Volume) }\end{array}$ & $\begin{array}{c}\text { Red Meat } \\
\text { (LowVolume) }\end{array}$ & $\begin{array}{l}\text { Red Meat } \\
\text { Processing } \\
\text { (Post DAF) }\end{array}$ & $\begin{array}{c}\text { Seafood } \\
\text { Processing }\end{array}$ & $\begin{array}{l}\text { Prepared } \\
\text { Meals }\end{array}$ & $\begin{array}{c}\text { Prepared Meal } \\
\text { Processing } \\
\text { Washdown } \\
\text { (post DAF) }\end{array}$ & $\begin{array}{c}\text { Olive Oil } \\
\text { Wastewater }\end{array}$ & Brewery & Textile \\
\hline Volume & & & & $215 \mathrm{kl} / \mathrm{h}$ & $40.1 \mathrm{kl} / \mathrm{h}$ & & & $\begin{array}{l}285 \mathrm{kl} / \mathrm{t} \\
\text { product }\end{array}$ & & & & \\
\hline $\mathrm{pH}$ & $6.2-11.3$ & $4-12$ & 4.6 & & & & $7.0-8.1$ & & 4.89 & $5.25 \pm 0.25$ & $6.98 \pm 0.28$ & $9.6-12.5$ \\
\hline $\mathrm{T}^{\circ} \mathrm{C}$ & & $15-40$ & & 31 & 44.9 & & & & & & & 60 \\
\hline $\begin{array}{l}\text { Conductivity } \\
(\mu \mathrm{S} / \mathrm{cm})\end{array}$ & & $>4000$ & & & & & & & 975 & $24,000 \pm 8000$ & $2330 \pm 99$ & \\
\hline TSS (mg/L) & $326-3560$ & & & 6600 & & & $150-1100$ & $200-3700$ & & & $660 \pm 52.9$ & $60-416$ \\
\hline $\begin{array}{c}\text { Total solid } \\
(\mathrm{mg} / \mathrm{L})\end{array}$ & $1837-14,205$ & & & 6828 & 6118 & $1200-7000$ & & & & $\begin{array}{c}90,000 \pm \\
36,000 \\
\end{array}$ & & \\
\hline $\mathrm{BOD}(\mathrm{mg} / \mathrm{L})$ & $565-5722$ & $>900$ & 35,000 & & & & $1600-4000$ & $310-3100$ & & & & $25-433.3$ \\
\hline $\mathrm{COD}(\mathrm{mg} / \mathrm{L})$ & 785-7619 & & & 12,460 & 10,925 & $2084-13,381$ & $1100-4800$ & $560-7000$ & 1808 & 156,000 & $3321.3 \pm 158$ & $1834.6-3828$ \\
\hline TOC (mg/L) & & & & & & & & & & $2500 \pm 7100$ & $898.3 \pm 31.9$ & $263.9-731.9$ \\
\hline FOG (mg/L) & & & 0.8 & 1240 & 1569 & $266-5953$ & $34-620$ & 82-2000 & & $6500 \pm 1300$ & & \\
\hline TKN (mg/L) & $14-140$ & & 1400 & 438 & 271.5 & $107.6-294.8$ & $240-570$ & $13-76$ & & & & \\
\hline $\mathrm{TP}(\mathrm{mg} / \mathrm{L})$ & 29-181 & $>45$ & 640 & 56 & 46.7 & $8.9-34.6$ & $260-460$ & $4-22$ & & $590 \pm 240$ & & \\
\hline $\mathrm{PO}_{4}(\mathrm{mg} / \mathrm{L})$ & 6-35 & & & 27 & 32.4 & $3.7-17.3$ & & & & & & \\
\hline $\begin{array}{c}\text { Sulphate } \\
(\mathrm{mg} / \mathrm{L})\end{array}$ & & $>600$ & & & & & 8-200 (Total S) & & & & & 700-2400 \\
\hline $\mathrm{Na}(\mathrm{mg} / \mathrm{L})$ & 263-1265 & $>600$ & 430 & 194 & 217 & & & & & & & \\
\hline $\mathrm{Ca}(\mathrm{mg} / \mathrm{L})$ & $1.4-58.5$ & & 1250 & 93.7 & 59 & & & & & & & \\
\hline $\mathrm{Mg}(\mathrm{mg} / \mathrm{L})$ & $6.5-46.3$ & & 100 & 22.6 & 32.6 & & & & & & & \\
\hline Source & [5] & [27] & [5] & [31] & [31] & [33] & [34] & [4] & [16] & [35] & [17] & [36] \\
\hline
\end{tabular}




\subsection{Classification of Trade Waste}

It is common for water service providers to prescribe certain limitations on the attributes of water entering the sewerage system, into which most trade wastes are released; one example is shown below in Table 2. $\mathrm{pH}$, temperature, dissolved and suspended solids, oxygen demand, oils and grease, nitrogen, and metals, among others, must all be brought to prescribed levels before discharging. [37].

Table 2. Discharge limits of parameters of interest, (example from City West Water, Melbourne, Australia [37]).

\begin{tabular}{cccc}
\hline Parameter & Allowable Range & $\begin{array}{c}\text { Maximum Concentration } \\
(\mathbf{m g} / \mathbf{L})\end{array}$ & $\begin{array}{c}\text { Maximum Daily } \\
\text { Load (kg/d) }\end{array}$ \\
\hline $\mathrm{pH}$ & $6-10$ & - & - \\
\hline $\mathrm{T}^{\circ} \mathrm{C}$ & $<38$ & - & - \\
\hline $\mathrm{TDS}$ & - & - & 200 \\
\hline $\mathrm{TSS}$ & - & $10,000 *$ & 1000 \\
\hline $\mathrm{BOD}$ & - & $4000 *$ & 1000 \\
\hline $\mathrm{FOG}$ & - & 0 (free floating) & - \\
\hline $\mathrm{TKN}$ & - & $500 \mathrm{~L}$ & - \\
\hline $\mathrm{NH} 4$ & - & $50+$ & 5 \\
\hline $\mathrm{Cu}$ & - & 10 & 100 \\
\hline $\mathrm{Fe}$ & - & 100 & - \\
\hline${ }^{*}$ Concentration limit only in effect if daily load exceeded; + higher limits applicable in certain circumstances.
\end{tabular}

In order to find efficient and purposeful end uses for the components of trade waste, the contents and properties of the waste must first be classified. A comparison of classification schemes can be seen in Table 3.

The most in depth, specialised method of evaluating a process for resource recovery suitability is a direct feasibility study. This usually entails employing an expert to assess a site's operations and make recommendations. This is a time intensive process, and involves sharing operational information which would otherwise be kept private. As a self-contained process, findings are not necessarily transferable as technology changes.

Another method of assessing recovery potential, which may yield less specific results, is establishing a reference range of values typical for a certain industry which can be extrapolated to estimate the materials which an untested facility will create. To do this, the typical concentration of components within trade wastes must be known from previous work or literature. Sites are identified by their industry, and the values adjusted by total waste flow volumes (from the untested facility) to calculate total resources available. In Spain, a project called "PROBIOGAS" studied the potential of agro-industrial biogas production. To do this, information about raw materials was compiled into a database. This database classified materials under 40 different codes [11]. These codes denoted individual waste streams, such as "citrus rejection" and "pork slurry". To apply this system to find potential recovery technologies, knowledge around the technologies available for each feedstock is required, instead of just highlighting the components of value. A drawback of this method is that unique trade waste components may be missed if they are not commonly found in the wider industry. 
Table 3. Comparison of classification methods for trade waste resource recovery potential.

\begin{tabular}{|c|c|c|c|c|}
\hline Classification Method & Summary & Advantages & Disadvantages & Example \\
\hline $\begin{array}{l}\text { Individual waste } \\
\text { stream } \\
\text { analysis }\end{array}$ & $\begin{array}{l}\text { An in-depth study } \\
\text { performed for or by an } \\
\text { individual site }\end{array}$ & $\begin{array}{c}\text { Unique, tailored recovery solutions } \\
\text { available } \\
\text { Can capture all information, as long as } \\
\text { it is measured } \\
\text { Can capture upstream and } \\
\text { downstream of current processing } \\
\text { units } \\
\text { Data is not made public, for business } \\
\text { privacy concerns } \\
\text { Usually a fully integrated process } \\
\text { from initial investigations, through } \\
\text { feasibility study, to construction and } \\
\text { operation of plant }\end{array}$ & $\begin{array}{l}\text { Potentially time } \\
\text { consuming } \\
\text { Potentially expensive } \\
\text { Low chance of } \\
\text { industrial synergy and } \\
\text { resource sharing } \\
\text { between companies } \\
\text { Low chance of } \\
\text { information sharing } \\
\text { Fixed at a point of time }\end{array}$ & [31] \\
\hline $\begin{array}{l}\text { Generic industry } \\
\text { grouping }\end{array}$ & $\begin{array}{c}\text { Classifying potential } \\
\text { sources by surveying } \\
\text { which industry they are } \\
\text { in, e.g., "Raw materials } \\
\text { of meat } \\
\text { slaughterhouse", or } \\
\text { "Beer bagasse" }\end{array}$ & $\begin{array}{c}\text { Easier to compile } \\
\text { Can be used for industrial synergy } \\
\text { studies } \\
\text { Can be used in computer aided } \\
\text { analysis, after some processing }\end{array}$ & $\begin{array}{l}\text { Knowledge required } \\
\text { about contents of each } \\
\text { industrial stream } \\
\text { Does not capture } \\
\text { unique attributes of } \\
\text { individual trade wastes }\end{array}$ & {$[11,28]$} \\
\hline Treatment volume & $\begin{array}{c}\text { Rating sites or areas by } \\
\text { trade waste outflow } \\
\text { volumes }\end{array}$ & $\begin{array}{c}\text { Indicates broad class of treatment } \\
\text { available } \\
\text { Suitable for large catchments }\end{array}$ & $\begin{array}{l}\text { Does not describe } \\
\text { contents of streams } \\
\text { Not suitable for } \\
\text { resource recovery } \\
\text { analysis }\end{array}$ & [9] \\
\hline $\begin{array}{l}\text { Standardised chemical } \\
\text { code }\end{array}$ & $\begin{array}{l}\text { Transforming raw trade } \\
\text { waste data for specific } \\
\text { parameters (e.g., COD, } \\
\text { TKN etc) into numeric } \\
\text { codes }\end{array}$ & $\begin{array}{l}\text { Can be used for industrial synergy } \\
\text { analysis } \\
\text { Unique resource fingerprint available } \\
\text { Can be used in automated databases } \\
\text { May be populated using data already } \\
\text { available to water utilities }\end{array}$ & $\begin{array}{l}\text { Will miss components } \\
\text { that are not measured } \\
\text { If data taken from } \\
\text { outflow measurements, } \\
\text { may not be able to } \\
\text { account for onsite } \\
\text { treatment }\end{array}$ & [38] \\
\hline
\end{tabular}

To allow for automation of the search for applications, while still capturing some unique characteristics of individual businesses, Hsien et al. [38] devised a 10-digit classification system for standardisation of this classification. $\mathrm{pH}$, total suspended solids (TSS), total dissolved solids (TDS), chemical oxygen demand (COD), the ratio of biological oxygen demand (BOD) to COD, total nitrogen (TN), total carbon (TC), total phosphorus (TP) and ions, minerals, and other metals (IM) were chosen as the important constituents, as well as a specific or "other" parameter for unique components that may require specialised treatment, such as FOG. Temperature was deliberately omitted from classification as it is a time-sensitive parameter. Ranges of measurement were influenced mainly by Singaporean waste specification but could easily be modified in line with any local provider's specifications. The classification system was designed based on the industrial synergy database published by Low et al. [39]. This database was developed to match suppliers' waste resources and customers' feedstock requirements, but minor adjustments, and expanding some capability, could result in a tool for easy identification of waste resource recovery technologies suitable for a classified trade waste stream.

Instead of material component streams, investigations into recovering waste heat energy survey must take note of exergy, i.e., the amount of work that can be performed as a system and its surroundings reach equilibrium. However, a major factor influencing exergy is the temperature of the source and surroundings [20]. Local investigations are vital, as differences in climate impact the viability of heat recovery. Higher ambient temperatures reduce exergy for a given waste stream. 
As well as classification by waste streams, classification by treatment system size is possible. Diaz-Elsayed et al. [9] classified small scale systems as up to $115 \mathrm{~m}^{3}$ with a 3-day retention time; medium scale as up to $20,000 \mathrm{~m}^{3}$ /day semi centralised systems; and large scale as centralised plants with over $3785 \mathrm{~m}^{3} /$ day. Overlap in volumes allowed for differentiation of plant configuration, where some smaller plants have centralised collection and treatment processes, like that of large municipal WWTPs. When classifying TWCs and their wastewater streams, the classification scheme described by Hsien et al. [38] seems most appropriate, with a balance between time and information required, and actionable results. This could be improved with an extra code for exergy. The original study was constrained by the probability of trade wastes being transported before being utilised. As on-site treatment can reduce the delay between source and sink that degrades thermal quality, exergy measurements may be suitable when assessing waste streams for on-site recovery. Further research is required to develop generic, cost effective classification schemes that can be applied by water service providers to entire municipalities. Additionally, absent is research into using such a classification program to combine waste streams to overcome shortfalls or achieve appropriate stoichiometric ratios for particular recovery technologies. The authors have not identified any formal analysis or study of classification schemes which has as its aim the determination of the most suitable scheme for widespread use in industrial resource recovery. Although there are many papers (as considered above) that are devoted to the design of such schemes, it is less common for these proposals to be tested in a practical setting. Comparison studies could lead to more efficient screening and uptake of resource recovery.

\section{Resource Recovery Technologies}

Meena et al. [23] reviewed resource recovery from wastewater from the perspective of the technologies used and form of the resources recovered. Many technologies were described, and challenges identified for each. This paper does not focus on the original wastes, or their contents, instead looking at individual technology studies that may use real or synthetic waste as feedstock. Municipal wastewater treatment was also reviewed by Diaz-Elsayed et al. [9]. Again, some of the information about technology across scale is transferable to the industrial sector, but sections focusing on home sewage and urine source separation are not.

\subsection{Chemical and Physical Processes-First Steps to Resource Recovery}

A common resource recovery model involves the use of relatively straightforward chemical reactions and physical processes. Analogs to these processes are likely already in place at many industrial sites, in order to bring trade waste within disposal guidelines.

The precipitation of fat, protein, BOD and turbidity from dairy wastewater through the addition of iron chloride $\left(\mathrm{FeCl}_{3}\right)$ has been shown to be effective at a laboratory scale. The treated water is suitable for cleaning purposes, and as $\mathrm{FeCl}_{3}$ is generally regarded as safe (GRAS), the recovered solids may be used directly for feedstock additives [40].

In another study, Kurup et al. [41] showed the possibility of using sodium lignosulphonate as a coagulating agent to recover lipids and casein proteins from dairy processing waste. As the final concentration of additive was far below European Food Safety Authority guidelines, it was suggested that the solids could be used as an animal feedstock. Whey proteins were not recoverable through this technology due to their small sizes and solubility in the tested conditions. Consequently, $\mathrm{FeCl}_{3}$ addition may be preferable, recovering $80 \%$ of protein mass (compared to $46 \%$ by sodium lignosulphate); the difference mostly comprised of whey proteins. These proteins may be valuable as food additives, being a source of essential amino acids [42].

To recover nutrients from pre-treated swine effluent, Song et al. [43] compared sequenced batch reactors with a reaction time of $1 \mathrm{~h}$, and a $6 \mathrm{~h}$ HRT continuous reactor, achieving phosphorus recoveries of $76.3 \%$ and $78 \%$, respectively. Using air stripping, the impurity $\mathrm{CO}_{2}$ was removed. The subsequent increase in $\mathrm{pH}$ caused the formation of 
struvite $\left(\mathrm{MgNH}_{4} \mathrm{PO}_{4}: 6 \mathrm{H}_{2} \mathrm{O}\right)$. Struvite is a crystalline fertiliser that is smaller in volume, and easier to transport to end users than biosolids sludge [3]. The authors noted that a large portion of $\mathrm{NH}_{3}$ from the effluent was also stripped and therefore not recovered as struvite. Butler [10] investigated commercial struvite technologies available overseas for their suitability for the Australian meat processing industry, as there were no known commercial plants in the country. By this time, air-stripping was a proven unit process in a number of plant scale systems. Comparisons between installations confirmed a significant saving by adjusting $\mathrm{pH}$ in this way, instead of using sodium hydroxide. Despite this, none of the scenarios showed a positive NPV. One of the main costs of operation at lab scale was electricity used to power aeration. At plant scale, the cost is influenced more by the requirement to dose magnesium to provide the correct stoichiometric ratios. Matching an alternate source of magnesium using classification schemes mentioned earlier in this review could make these systems feasible. This too requires further study.

A common physical treatment method is the use of grease traps [44] to partition FOG. The less dense oil is separated from the water through settling. If FOG is discharged to sewer, it can cause obstructions and overflows by forming solid deposits on pipe interiors [6]. Muthukumaran and Baskaran [34] suggested that screen filters and solid separators could prevent suspended solids and entrained FOG from leaving with wastewater but did not provide any uses or disposal methods for the solids captured.

One potential use is conversion to biodiesel [44,45]. Although grease trap waste (GTW) is plentiful, it must be pre-treated to purify lipids. Tran et al. [45] achieved this with a 1:1 $(v / w)$ ratio of hexane to GTW, of which $88 \%$ was reuseable. In industrial application, trade-offs must be made between high lipid recovery, and economic reaction times. The purified lipids then underwent esterification and transesterification reactions with acetone and ethanol to form crude biodiesel. The crude biodiesel was then distilled to produce diesel fuel at a commercial quality. These processes were not yet economical compared to mineral diesel [45]. As the ethanol required for this reaction must be anhydrous, feedstock costs were high. Use of a supercritical, non-catalysed reaction shows promise in being able to utilise ethanol with a $2.5 \%(w / w)$ water content [46]. Whether the benefits of cheaper feedstock are counteracted by the capital and operating costs of a high temperature, high pressure process is unknown, and the technology is yet to be scaled up.

Using waste oil as a medium for fry-drying of waste sludge has also been shown to be an effective method of utilising two waste streams. Removing water from sludge, while also adding energy rich oil produces a combustible, transportable solid fuel. Romdhana et al. [47] found the energy content of processed sludge to be high enough for auto-combustion. However, NOx and SOx levels in combustion gases may be above emission restrictions, so applications may be limited [18]. Wu et al. [48] concluded that the weight ratio of oil to sludge treated could be as high as 1:8 but noticed that phosphorus transferred from sludge to oil phases during this treatment. Recovery of phosphorus from the oil is a potential avenue for investigation. These papers seem to solve issues which Causer [49] noted in gas mediated torrefaction, such as the danger of auto-ignition and condensation of tars onto equipment, but do not attempt to quantify the off gases or energy requirements of the process. Do et al. [50] completed a mass and energy balance for a related vacuum fry-drying/torrefaction process in ASPEN. This simulation, using meat processing waste as a feedstock, showed that the process produced a fuel product with $40 \%$ more energy than it consumed. This meant that two thirds of the fuel could be used in the process, and one third could be sold on. The flue gases were found to be within their relevant emissions standards in this case. Actual practical studies are required for off-gas quantification and industrial use of the process.

\subsection{Membrane Technology-Separating Valuable Resources \\ 4.2.1. Forward Osmosis}

Forward osmosis (FO), shown in Figure 2, is a separation technology where water from a feed stream is drawn through a semi-permeable membrane into a draw solution, with the 
difference in concentration and resulting osmotic pressure as the driving force. This results in the feed stream becoming concentrated, and the draw solution collecting water. The draw solution can then be disposed of or treated further to reconcentrate and regenerate it for reuse and provide a pure water stream. Although FO is applicable as a pre-treatment step for decreasing membrane fouling in other technologies [51], one important drawback to note is the possibility of solute flux across the membrane, both from DS to FS and vice versa. Any FS chemical that can permeate through the membrane may accumulate and be concentrated in the DS regeneration process, and passage of draw solute back into the feed solution can add unwanted ions into the concentrate [52]. This can be somewhat mitigated by the addition of surfactants to the draw solution of a FO system. For example, Triton $\mathrm{X}-114$ at concentrations below $1.5 \mathrm{mM}$ can decrease reverse diffusion of salt by forming a layer on the membrane surface that constricts pores [53]. However, this study did not evaluate the impact of surfactant treatment on contamination of the draw solution, which is an area for future investigation.

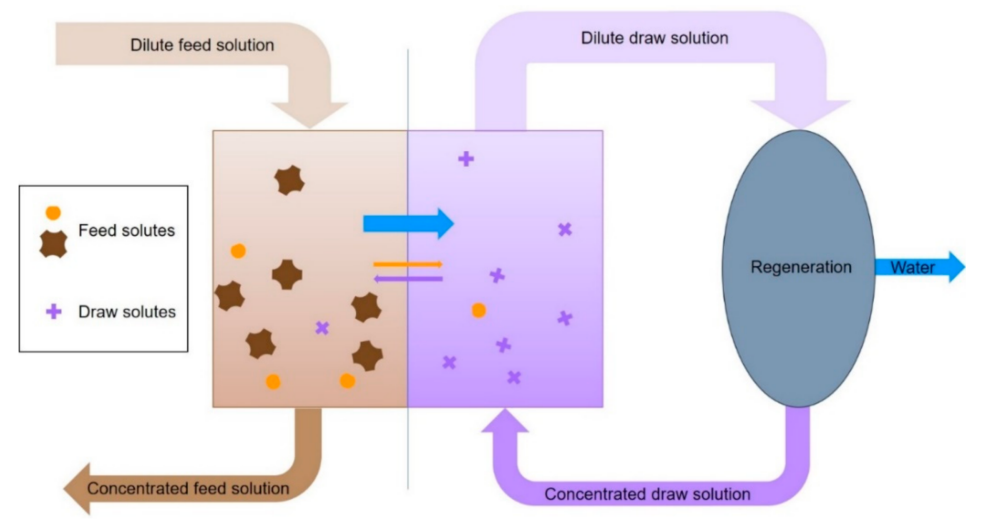

Figure 2. Forward Osmosis. Large volume of dilute wastewater (feed stream) enters. Lower volume of concentrated wastewater exits module. Water crosses the membrane due to osmotic pressure, diluting the draw solution. The draw solution can be regenerated by an external process, and the clean water stream removed. Some draw solute diffuses to the feed solution. Some feed stream components diffuse to the draw solution, where they may be concentrated by regeneration process.

Seawater, cooling tower bleed water and cheese brine can be used as DS to varying levels of success $[54,55]$, allowing an addition of value to the FS through dewatering, while diluting waste DS for non-potable reuse or disposal.

\subsubsection{Gas Permeable Membranes}

He et al. [56] studied the batch recovery of ammonia as ammonium sulphate using custom gas permeable filter sheets as a separation medium, and sulphuric acid as a reagent. Under ideal conditions, $75.9 \%$ of Total Ammonia Nitrogen (TAN) was recovered from landfill leachate after $6 \mathrm{~h}$, with a mass transfer coefficient of $1.24 \times 10^{-5} \mathrm{~m} / \mathrm{s}$. This was performed with a ratio of wastewater to sulphuric acid of 3:1. This relatively high quantity of acid, along with further recovery steps of filtration, evaporation and crystallisation, and the batch nature, mean further refinements are required for large scale industrial use.

\subsubsection{Membrane Distillation}

Membrane distillation, shown in Figure 3, works by using a hydrophobic membrane between two solutions. High surface tension prevents liquid water from passing through the membrane, while a temperature difference between the chambers creates a vapour pressure driving force. Solvent vaporises on the high temperature side, passes through the membrane, and condenses on the low temperature side [57]. At its most basic, this can separate a liquid into a pure solvent (cold side) and a concentrated solution (hot side). Waste heat is a potential economical energy source for this process, as the operating temperature can be as low as $70^{\circ} \mathrm{C}$, with a difference across the membrane of $20^{\circ} \mathrm{C}$ [58]. 


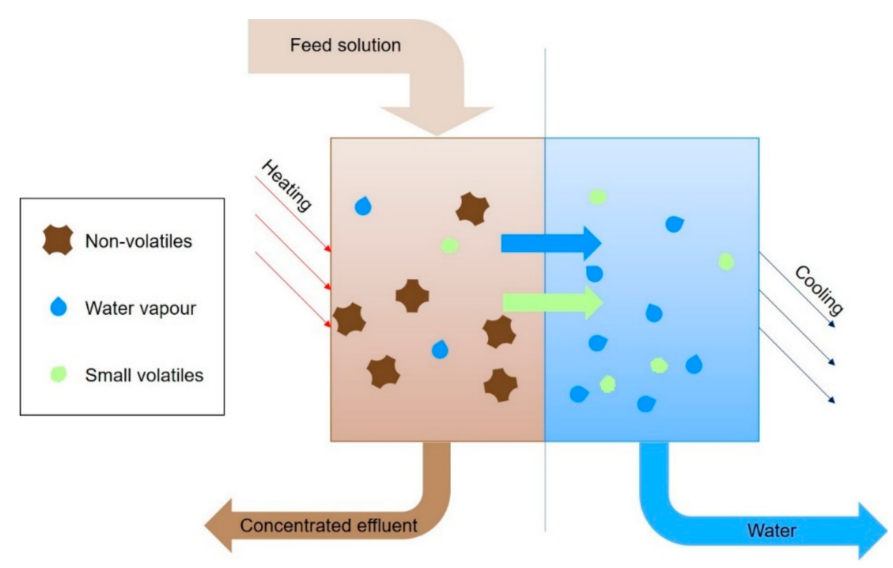

Figure 3. Membrane distillation. Large volume of dilute wastewater enters. A lower volume of concentrated wastewater exits the module, after addition of heat allows water vapour and other volatiles to cross the membrane. Heat is removed on the condenser side, and vapours condense into the water stream.

A key issue with MD is that the membranes are not completely specific, and other small, volatile molecules, such as ammonia, can pass through [59]. This can be exacerbated by accumulation of contaminants such as carbonate ions, which may increase $\mathrm{pH}$ on the feed side. $\mathrm{pH}$ changes impact the volatility of ammonia as per $\mathrm{NH}_{3}+\mathrm{H}_{2} \mathrm{O} \leftrightarrow \mathrm{NH}_{4}^{+}+\mathrm{OH}^{-}$[60]. However, if carbonate is not the predominant compound, or if acid is formed in the feed stream, $\mathrm{pH}$ can decrease, and ammonia volatility with it [61].

The selection of membrane composition is important for efficient operation due to the surface properties and chemical compatibilities of each polymer. Memsys Water Technologies $\mathrm{GmbH}$ [62], manufacturer of MD systems, note that the water to be treated must have below $100 \mathrm{ppm}$ of oil and surfactants, as these contaminants lower surface tension, allowing solvent through the membrane. Free chlorine and some other chemicals are contraindicated, as they will destroy the membrane structure. A lifespan of two years or higher is suggested. Using experimental specialty membranes has been shown to overcome issues with oil and surfactant chemicals at a laboratory scale [63].

As with any membrane separation technology, scaling and fouling affects MD [61]. According to manufacturers, standard caustic and acid clean in place procedures can be used effectively to clear fouling [21]. Guillen-Burrieza et al. [64] however, found that PTFE membranes used in plant scale desalination suffered from worse longevity (Mullen burst pressure) than unused membranes depending on cleaning techniques. Citric, sulfuric, formic, and oxalic acids, and an EDTA/detergent mixture were used to remove inorganic scaling, but alkaline treatments were not tested, as the authors decided that it was not applicable, due to minimal biological fouling on the sample membrane available to them. No treatment can return the membrane to original condition. Zhao et al. [65] also found that cleaning treatments damage membranes, in this case when an acetate FO membrane was cleaned with a sodium hypochlorite solution to remove biological fouling. Unfortunately, even if adequate cleaning is achieved within the limits of membrane integrity, it can take large quantities of water, and is quickly spoiled if storage is inadequate when the membranes are out of service. As such, Guillen-Burrieza et al. [64] determined that prevention of fouling is easier and more effective than a cleaning regime. Fouling prevention methods may include use of suitable membrane material, operating conditions, and configuration [66]. As mentioned in a previous section, FO units may be one way to reduce fouling.

El-Abbassi et al. [35] showed that polyphenols could be concentrated from olive mill wastewater using commercial MD membranes at laboratory scale, and later refined the process by adding a microfiltration (MF) pre-treatment step [30]. This was shown to reduce fouling, providing a higher flux than the untreated wastewater over a longer period. It is notable that MF is a less expensive pre-treatment than the ultrafiltration studied elsewhere. 
At pilot scale, an application of MD has been trialled in an electroplating process at Roto Frank Austria GmbH. In the standard process, metal parts are dipped in a passivation chemical bath, before being rinsed in a water vessel. Entrainment of liquid on the metal surface results in a constant loss of expensive passivation chemical, and the contamination and consequent disposal of the rinse water. Using membrane distillation, contaminated rinse water can be purified and returned to the rinse bath, and concentrate can be recycled to the passivation liquid. Water savings of $93 \%$ and passivation chemical savings of $60 \%$ were reported [12]. Utilisation of this process is likely the product of individual waste stream analysis, and probably would not have been indicated by more generic investigations.

Stand-alone MD systems suffer from a number of issues hindering commercialisation [14], but can be used in combination with forward osmosis, crystallisers, and bioreactors, among others, combining strengths and negating weaknesses.

Struvite production can be enhanced, and a reusable water stream produced, in a hybrid FO/MD. Xie et al. [67] used digested sludge centrate as a feed and magnesium chloride as a draw solution to harness the reverse flux phenomenon. Water was drawn through the FO membrane, concentrating phosphate and ammonium ions to levels conducive for struvite production. Magnesium diffused back from the draw solution to the centrate, providing the otherwise limiting ions. MD was used to regenerate the DS. Increased $\mathrm{pH}$ from the FO process proved beneficial, but as the highest removal efficiency for struvite is achieved at $\mathrm{pH} 9.5$ [68], collection of struvite crystals was made possible by lowering the $\mathrm{pH}$ of the treated centrate and allowing to crystallise for $2 \mathrm{~h}$. A further drop in $\mathrm{pH}$ may have been achieved by stripping $\mathrm{CO}_{2}$ from the centrate using air, as discussed earlier $[43,69]$. However, concentration of impurities, especially calcium, has a large impact on struvite production [68], a fact that was ignored. Calcium impurities can be precipitated out from mixed wastewater as $\mathrm{CaCO}_{3}$ and reduced to great effect in under $5 \mathrm{~min}$ by the pre-treatment addition of $\mathrm{NaCO}_{3}$, resulting in a higher purity struvite product [70]. The efficiency of $\mathrm{pH}$ correction and potential decrease in membrane fouling by sparging air within the reactor, should be subject to further study, in combination with the effects of calcium removal.

In order to further improve the efficiency and lower capital costs of running different technologies in combination, Kim et al. [54] described an osmotically and thermally isolated integrated FO-MD system. Draw solution was concentrated by passing the MD membrane, before flowing past a barrier, around to an FO membrane where it drew water from the feed. This configuration leveraged the efficiency of counter-current heat and mass exchange, increasing temperature and concentration gradient driving forces. While this operation was simulated, a pilot scale test is planned. The mass and heat transfer principles can be used in the design of any combination system.

\subsection{Bioreactors-A Growing Field for Resource Recovery}

A large number of products can be extracted from fermentative processes. A summary of the key considerations in respect of bioreactor use in resource recovery can be found in Table 4. Whey has been used as a feedstock for production of carotenoids, xanthan gum, and lysozymes [26]. These high value products must be assessed individually, as profitability depends on finding a customer. More widely applicable products recoverable from bioreactors, such as fuels and water, are more likely to be the result of utilising a generic classification scheme in screening potential trade waste sources.

In order to reclaim or pre-treat reusable water, membrane bioreactors (MBR) can be used. COD is consumed by the microbes within the sludge and converted to larger molecules that cannot pass the membrane. Dynamic membrane (DM) bioreactors are one configuration of MBR. A DM is a cake layer that forms on an inexpensive support mesh. An initial mesh pore-size of $10 \mu \mathrm{m}$ results in efficient COD removal from cheese whey wastewater, but relatively low $(\sim 80 \%)$ solids removal. A larger pore size allows even greater solids passage [71]. This may be suitable as an initial treatment for high strength wastewater but will not produce reusable water. To this end, Choi et al. [72] utilised a 
nano-filtration MBR (NFMBR). In aerobic treatment, with the separation driving force being provided by intermittent suction, low TOC water was produced from synthetic wastewater. Phosphorus and nitrogen in the permeate and reactor were found to be at similar levels throughout operation, limiting applications for water or nutrient recovery. The cellulose acetate membrane used also suffered from biodegradation. Flux through the membrane showed changes due to suction pressure choices, as well as fouling.

Removing pressure as a driving force, Phattaranawik et al. [73] designed and tested bench-scale submerged Membrane Distillation Bioreactor (MDBR) processes, involving membrane distillation rigs immersed in thermophilic aerobic reactors. One rig was a double-faced flat sheet module, while the other consisted of membrane tubes. Using synthetic wastewater, their flat sheet module had high initial flux, which dropped over time, while their tubular array showed lower initial flux which remained stable over the two-week trial. The authors concluded that, compared to Choi et al. [72]'s NFMBR, MDBR showed better flux. It is not simple to compare the two different technologies in this way, as there are many variables between the two, including original loading, and the effects of pressure change. This report did not mention the retention of phosphorus but did note that ammonia was found in the permeate, using both PVDF and PTFE membranes. Kim et al. [74] also combined MBR with MD, but under anaerobic conditions. Despite a removal of up to $92 \%$ COD and practically all phosphate, they found high levels of ammonia flux through PVDF MD membranes and concluded that this was due to ammonia's volatility. Qiu et al. [59] performed vacuum membrane distillation followed by conventional vacuum fractional distillation on piggery wastewater anaerobic digestate. The atmospheric distillate contained over $7000 \mathrm{~g} / \mathrm{L} \mathrm{TN}$, mostly as ammonia, giving a separation factor of 114 . The vacuum distillate was $80 \%$ of the original feed water, with relatively low concentrations of other compounds, suitable for reuse. Membrane distillation intuitively shows promise in conjunction with thermophilic bioreactors due to higher energy efficiency, however research into scale-up and increased flow rates are required.

Anaerobic digesters convert less carbon to biomass than aerobic reactors, instead forming biogas. Biogas contains methane and carbon dioxide and can be used as a power source. Simple digesters are currently in use at plant scale globally [22], but anaerobic membrane bioreactors (AnMBR) can increase efficiency and decrease hydraulic retention times. Treated effluent can leave the reactor, while mature sludge is retained. Carbon may still be lost to permeate, however, as methane is relatively soluble in water: up to $67 \%$ of that produced in an AnMBR may pass through membranes and be lost, especially in low strength wastewater at low temperatures [75]. During the start-up period of an AnMBR, VFAs are produced, which may also flow to the permeate [61,65]. How these losses may be prevented is an important area of further study.

Ogejo and $\mathrm{Li}$ [76] treated flush dairy manure (green waste) and turkey processing waste (red waste) together in an anaerobic digester to recover biogas. In this case, biogas production increased with the volume percent of red waste in the feed. Pure red waste was shown to produce higher quality biogas at higher volumes per kilogram of volatile solids, but it was unclear whether co-digesting the two streams gave better results than the sum of digesting each feed separately. Mixed feeds did not show chemical concentrations fitting linear ratios of the two pure streams as expected, so results may have been impacted by factors other than the overall red waste:green waste ratio. A simplified economic analysis showed that different ratios of effluent feed provided different levels of economic benefit, confirming that combining waste streams or changing operating methods changes the economics of treatment [77]. Using waste FOG to double volatile solids load has been shown to increase biogas production by $170 \%$. Cultivating a suitable sludge is a major factor in biogas production, and the microbial community of this anaerobic bioreactor had acclimatised to VFAs over 90 days [78]. Studies of trade waste combinations are required to determine the factors influencing biogas production in mixed streams, and the potential impact on resource sharing using classification schemes (such as Hsien et al. [38]). 
Jensen [33] took an industry-based approach to AnMBR at pilot scale at two Australian red meat processing plants. Despite acknowledging that improvements could be made, and that more research was needed for higher organics loading, economic analysis showed that operating the system was cash positive. This was mostly due to the energy value of biogas, and a significant value of captured nutrients. Capital and ongoing costs were lower for a more optimised and intensified process, with a theoretical payback period of under 4 years.

Membranes can also be used to selectively remove other volatiles from reaction liquor. Tomaszewska and Białończyk [79] produced ethanol from yeast fermentation of pre-treated acid whey; first removing proteins and enzymatically hydrolyzing lactose in concentrated whey, then enriching with sucrose, the $24 \mathrm{~h}$ fermentation reached efficiencies above $90 \%$ when ethanol was continuously removed into a PP MD distillate stream. Inhibition from the ethanol was decreased, but issues with the concentration of salts in the fermentation media were raised. Utilising a sidestream UF system that allows removal of saline water while retaining and reconcentrating the fermentation broth may be an avenue for further study.

As a membrane process, flux in MBRs can decrease over time. Lin et al. [80] compared the sludge properties and fouling potential of mesophilic vs. thermophilic submerged AnMBRs. Using a Kraft paper production effluent as feedstock, each reactor began under identical conditions, apart from the temperature. In this case, it was found that the reactor at $55^{\circ} \mathrm{C}$ created smaller floc particle sizes than the reactor at $37^{\circ} \mathrm{C}$. This resulted in higher fouling on the microfiltration membrane.

Adding GAC to a fluidised bed AnMBR can reduce membrane fouling and reduce protein and carbohydrate concentrations in liquor and the cake layer. In a $5.6 \mathrm{~L}$ reactor, severe biofouling was delayed by $60 \%$ by the addition of $40 \mathrm{~g} \mathrm{GAC}$, and by $230 \%$ when $80 \mathrm{~g}$ GAC was added [81]. The cake layer can also be managed by sparging biogas past the membrane [71].

Ion exchange has been shown to have some applications as a co-treatment at laboratoryscale. Johir et al. [82] described a post-MBR ion exchange resin treatment. Phosphate and nitrate from MBR effluent was captured in a resin column and could be recovered by regenerating the system with saltwater. Ammonia in the original simulated waste was converted to nitrate under aerobic conditions. If ion exchange is performed as a post treatment for AnMBR, ammonium and phosphate ions can be recovered, and used to produce struvite [83]. Due to price and scale issues, ion exchange is unlikely to have wide use in industrial settings, unless recovering highly valuable chemicals.

\subsection{Microbial Fuel Cells-Potential for the Future}

Microbial fuel cell (MFC) technology uses electrogenic bacteria to oxidise organic matter. Selection of suitable cathodes and anodes allows production of an electrical current. Utilizing this process, Boghani et al. [16] achieved COD decreases of $84 \%$ in food processing washdown water. After pre-treatment in a DAF, COD levels in the initial feed were only $1.14 \mathrm{~g} / \mathrm{L}$ and were decreased to around $0.20 \mathrm{~g} / \mathrm{L}$ by the MFC, with a total reaction time of 18 days. Although feasible in that the electricity generated was more than the electricity required for heating and pumping of the system, treating only $2 \mathrm{~L}$ of wastewater over 18 days may not be scalable to industry in this form. Dong et al. [17] achieved energy selfsufficiency in a $90 \mathrm{~L}$ working volume modular reactor. Approximately $0.49 \mathrm{~kg}$ TCOD $/ \mathrm{m}^{3} / \mathrm{d}$ was removed from brewery wastewater; however, the treated water still contained over $400 \mathrm{mg} / \mathrm{L}$ of TCOD, making it unsuitable for reuse without further treatment. The authors did note this, suggesting the possibility of increasing the number of modules. They also indicated that external biomass recirculation could help increase SRT while allowing for short HRT. Membrane technology may also achieve this [15] but could impact the relatively tight energy balance. Further studies aimed at investigating this are necessary. Considering the reactor size, retention time and average quantity of waste per volume of beer produced [4], the reactor volume in plant operation may have to be over $2.5 \times$ the daily production volume. 
Table 4. Summary of bioreactor resource recovery technologies.

\begin{tabular}{|c|c|c|c|c|c|}
\hline & Technology & Description & Advantage & Limitation & Studies \\
\hline & Bioreactor & Reactor using biological systems & $\begin{array}{c}\text { Can degrade complex COD } \\
\text { Can produce certain products (e.g., ethanol) } \\
\text { Lower chemical use than traditional processes }\end{array}$ & $\begin{array}{l}\text { Washout of sludge possible } \\
\text { Low reaction rates }\end{array}$ & [76] \\
\hline & $\begin{array}{c}\text { Membrane } \\
\text { Bioreactor (MBR) }\end{array}$ & $\begin{array}{c}\text { Bioreactor integrating membrane separation } \\
\text { technology } \\
(\mathrm{DM} / \mathrm{MF} / \mathrm{UF} / \mathrm{NF} / \mathrm{RO} / \mathrm{FO} / \mathrm{MD})\end{array}$ & $\begin{array}{l}\text { Decouples SRT and HRT, allowing removal of } \\
\text { products and inhibitory compounds, while } \\
\text { mature sludge remains }\end{array}$ & See limitations of membranes below & [75] \\
\hline \multirow{3}{*}{ Conditions } & Thermophilic & Relatively high temperature conditions $\left(\sim 55^{\circ} \mathrm{C}\right)$ & $\begin{array}{l}\text { Higher reaction rate } \\
\text { Can kill pathogens }\end{array}$ & $\begin{array}{l}\text { High energy costs } \\
\text { Higher fouling }\end{array}$ & [80] \\
\hline & Mesophilic & Medium temperature conditions $\left(\sim 37^{\circ} \mathrm{C}\right)$ & Lower energy costs & Relatively lower reaction rate & [80] \\
\hline & Anaerobic & Oxygen not present in reactor vessel & Certain products, such as biogas & Low rate & [76] \\
\hline \multirow{7}{*}{ Membranes } & Dynamic Membrane (DM) & $\begin{array}{c}\text { 10-70 } \mu \mathrm{m} \text { mesh provides support for accumulation } \\
\text { of cake layer, which acts as filter; applied pressure } \\
\text { as driving force }\end{array}$ & $\begin{array}{l}\text { Low cost } \\
\text { Smaller mesh can filter solids }\end{array}$ & $\begin{array}{l}\text { Larger mesh allows solids to } \\
\text { permeate } \\
\text { Does not remove all COD from } \\
\text { permeate } \\
\text { Membrane fouling can occur }\end{array}$ & [71] \\
\hline & Microfiltration (MF) & $\begin{array}{l}\text { Smaller pore size }(\sim 0.1 \mu \mathrm{m}) \text { membrane acts as filter; } \\
\text { applied pressure as driving force }\end{array}$ & Removes suspended solids and bacteria & \multirow{3}{*}{$\begin{array}{l}\text { Increasing pressure requirements } \\
\text { Increasing cost } \\
\text { Increasing pre-treatment } \\
\text { requirements }\end{array}$} & {$[38,80]$} \\
\hline & Ultrafiltration (UF) & $\begin{array}{l}\text { Smaller pore size }(\sim 0.01 \mu \mathrm{m}) \text { membrane acts as } \\
\text { filter; applied pressure as driving force }\end{array}$ & Additionally, removes viruses & & \\
\hline & Nanofiltration (NF) & $\begin{array}{l}\text { Smaller pore size }(\sim 0.001 \mu \mathrm{m}) \text { membrane acts as } \\
\text { filter through size exclusion and electrostatic } \\
\text { interactions; applied pressure as driving force }\end{array}$ & Additionally, removes some ions & & [72] \\
\hline & $\begin{array}{c}\text { Reverse } \\
\text { Osmosis (RO) }\end{array}$ & $\begin{array}{l}\text { Smaller pore size }(\sim 0.0001 \mu \mathrm{m}) \text { semi-permeable } \\
\text { membrane acts as filter; applied pressure as driving } \\
\text { force }\end{array}$ & Potable water production & Brine disposal can be difficult & \\
\hline & $\begin{array}{l}\text { Forward } \\
\text { Osmosis (FO) }\end{array}$ & $\begin{array}{l}\text { Semi-permeable membrane allows water to } \\
\text { permeate from feed solution to draw solution; } \\
\text { osmotic pressure as driving force } \\
\text { ( Figure 2) }\end{array}$ & $\begin{array}{c}\text { Low pressure } \\
\text { Can use waste streams as draw solutions } \\
\text { Lower fouling } \\
\text { Can use draw solute as source of chemicals for } \\
\text { reaction }\end{array}$ & $\begin{array}{c}\text { Draw solution requires regeneration } \\
\text { if being re-used } \\
\text { Bidirectional diffusion of some } \\
\text { solutes } \\
\text { Draw solute lost to feed solution } \\
\text { Impurities concentrated in draw } \\
\text { solution }\end{array}$ & {$[53,55,65]$} \\
\hline & Membrane Distillation (MD) & $\begin{array}{l}\text { Hydrophobic membrane allows only small volatile } \\
\text { molecules to diffuse; vapour pressure gradient } \\
\text { (temperature difference) as driving force } \\
\text { ( Figure } 3 \text { ) }\end{array}$ & $\begin{array}{c}\text { Low pressures } \\
\text { Can use waste heat } \\
\text { Lower fouling } \\
\text { High rejection of non-volatiles } \\
\text { Not impacted by feed concentration }\end{array}$ & $\begin{array}{l}\text { Unwanted volatile compounds, e.g., } \\
\text { ammonia, can collect in condensate } \\
\text { Limited commercial availability }\end{array}$ & [79] \\
\hline
\end{tabular}


Table 4. Cont.

\begin{tabular}{|c|c|c|c|c|c|}
\hline & Technology & Description & Advantage & Limitation & Studies \\
\hline \multirow{3}{*}{ MD membrane materials } & Polyvinylidene fluoride (PVDF) & MD membrane material & Lower fouling & Higher wetting and breakthrough & [74] \\
\hline & Polypropylene (PP) & MD membrane material & Lower fouling & Low flux & {$[57,74]$} \\
\hline & Polytetrafluoroethylene (PTFE) & MD membrane material & High initial flux & Fouling & [74] \\
\hline \multirow[t]{2}{*}{ Membrane configuration } & Spiral bound & $\begin{array}{l}\text { Alternating layers of membrane and supports, } \\
\text { wound into a spiral }\end{array}$ & Smaller footprint & $\begin{array}{l}\text { Complex construction } \\
\text { Increased energy efficiency } \\
\text { Fouling }\end{array}$ & [72] \\
\hline & Hollow fibre & Fibres of membrane material & Smaller footprint & $\begin{array}{l}\text { Complex construction } \\
\text { Fouling }\end{array}$ & [73] \\
\hline \multirow{2}{*}{ Fouling control } & Sparging & $\begin{array}{c}\text { Gas bubbled past membrane } \\
\text { Can use oxygen for aerobic systems, or biogas for } \\
\text { anaerobic systems }\end{array}$ & $\begin{array}{c}\text { Decreased fouling } \\
\text { Can increase } \mathrm{pH} \text { by removing } \mathrm{CO}_{2}\end{array}$ & $\begin{array}{c}\text { High energy costs } \\
\text { Can remove valuable components, } \\
\text { e.g., ammonia }\end{array}$ & [33] \\
\hline & Granulated activated carbon (GAC) & $\begin{array}{c}\text { Granulated activated carbon added and pumped } \\
\text { past membrane }\end{array}$ & $\begin{array}{l}\text { Decreased membrane fouling due to scouring } \\
\text { effect and absorption of proteins onto GAC }\end{array}$ & $\begin{array}{l}\text { High cost } \\
\text { GAC needs to be regenerated }\end{array}$ & [81] \\
\hline
\end{tabular}




\subsection{Thermal Energy Capture-Running Hot and Cold}

In the field of thermal energy recovery from water, most literature and available industry material considers sewer mining and is not specific to trade waste. Although this is largely transferable, industrial wastewater can exhibit certain unique properties, especially if they are source separated. One stream with unique properties is textile wastewater. As it can be found at $60^{\circ} \mathrm{C}$, there is significant exergy, but COD content may make it more suitable for biological resource recovery. The thermal energy in this case may be coincidentally used to heat reaction vessels [36].

Choices of technology can depend on a number of factors, including temperature of waste stream. Oluleye et al. [19] formulated a framework for screening different methods. This screening was generic for all material streams across given temperature bands but technologies in the $<50-100{ }^{\circ} \mathrm{C}$ range may be applicable to trade wastes. Comparing energy degradation, the most efficient technology for various temperature ranges was shown. Suggestions included upgrading heat through heat pumps, using heat exchangers for direct transfer, absorption chilling, and electricity generation through Organic Rankine Cycles (ORC). Installations of these technologies are not frequently the subject of literature, but one study examined ORC using wastewater from a steel mill as a heat source. High temperature wastewater was measured at $70-90{ }^{\circ} \mathrm{C}$, with a flow rate of $350 \mathrm{~m}^{3} / \mathrm{h}$. Power generation ranges of $212 \mathrm{~kW}$ to over $800 \mathrm{~kW}$ at $90^{\circ} \mathrm{C}$ were calculated, using R245fa working fluid [84].

In general, industry generates a large amount of waste heat [20]. Some thermal energy is found in treated water and cooling applications, among others, but capturing this energy is currently only rarely viable. Waste heat recovery is more regularly achieved through solid and gaseous streams, which are outside of the scope of this review.

\section{Conclusions}

At present, the majority of resource recovery literature is focused on mixed municipal wastewater, or is applicable only at small scale, and information about trade waste is limited. However, trade wastes present a promising avenue for resource recovery. Nutrients, energy and fuels can be claimed from suitable wastewater using physical, chemical and biological processes, or combinations thereof. Biogas production in anaerobic digesters and struvite production using chemical additives and crystallisers are currently the most common methods of recovering COD and nutrients, but membrane technology, whether forward osmosis, membrane distillation, or otherwise, is poised to improve the efficiency and economics of both. Potential exists for financial benefits to industry and businesses, and environmental benefits for the wider community from application of these processes.

Despite interest, uptake of resource recovery technologies remains low, or not widely championed. For this to change, knowledge needs to increase in several key areas. The contents and availabilities of trade wastes need to be classified, in order to make informed choices about resource recovery methods.

A practical comparison of screening and selection methods is required to determine the viability of generic methods in identifying potential resources for recovery. The classification schemes developed to date range from individual waste stream analyses, to generic industry grouping, to standardised chemical codes. Research into classification and screening also extends to finding appropriate combinations of feedstock, and whether automated systems can connect sources. A focus on magnesium sources for struvite production is particularly interesting.

Resource recovery technology also needs to be improved and proven to work with trade waste. Membrane separation in combination with bioreactors is an area requiring further research, with a focus on fouling minimization through sparging and additives, as well as reducing loss of dissolved methane and VFAs.

Production of biogas has some uptake, but struvite precipitation, despite promise, is not viable economically in Australia. Resource recovery needs to be improved and made 
economically and environmentally viable at plant scale, and the positive outcomes made clear to industry.

Author Contributions: Conceptualisation, J.A.K.E. and A.S.B.; methodology, J.A.K.E.; validation, J.A.K.E. and A.S.B.; formal analysis, J.A.K.E.; investigation, J.A.K.E.; resources, A.S.B.; data curation, J.A.K.E.; writing—original draft preparation, J.A.K.E.; writing—review and editing, A.S.B.; visualization, J.A.K.E.; supervision, A.S.B.; project administration, J.A.K.E. and A.S.B.; funding acquisition, A.S.B. All authors have read and agreed to the published version of the manuscript.

Funding: This research was supported by City West Water. The authors acknowledge the support received for research through the provision of an Australian Government Research Training Program Scholarship.

Acknowledgments: The authors would like to acknowledge support by Ben Fraser and Rachel Meinig.

Conflicts of Interest: The authors declare no conflict of interest. The funders had no role in the design of the study; in the collection, analyses, or interpretation of data; in the writing of the manuscript, or in the decision to publish the results.

\section{References}

1. Park, C.; Allaby, M. Trade effluent. In A Dictionary of Environment and Conservation, 3rd ed.; Oxford University Press: Oxdord, UK, 2017.

2. Skinner, W.W.; Sale, J.W. A study of sewage and trade wastes at Bridgeport, Connecticut. J. Frankl. Inst. 1921, 192, 785-799. [CrossRef]

3. Diaz-Elsayed, N.; Rezaei, N.; Ndiaye, A.; Zhang, Q. Trends in the environmental and economic sustainability of wastewater-based resource recovery: A review. J. Clean. Prod. 2020, 265, 121598. [CrossRef]

4. Tarbox, M. Effluents from food processing I composition and analysis. In Encyclopaedia of Food Science, Food Technology and Nutrition, 2nd ed.; Academic Press: London, UK, 2003; pp. 1991-1996.

5. Britz, T.J.; Van Schalkwyk, C.; Hung, Y.-T. Treatment of dairy processing wastewaters. In Waste Treatment in the Food Processing Industry; Wang, L.K., Ed.; Taylor \& Francis: Boca Raton, FL, USA, 2006.

6. He, X.; de los Reyes, F.L.; Leming, M.L.; Dean, L.O.; Lappi, S.E.; Ducoste, J.J. Mechanisms of fat, oil and grease (fog) deposit formation in sewer lines. Water Res. 2013, 47, 4451-4459. [CrossRef]

7. City West Water. Customer Charter 2018-2023 Trade Waste; City West Water: Melbourne, Australia, 2018. Available online: https:/ / www.citywestwater.com.au/sites/default/files/attachments/trade_waste_customer_charter.pdf (accessed on 3 May 2020).

8. Hall, M.R.; Priestley, A.; Muster, T.H. Environmental life cycle costing and sustainability: Insights from pollution abatement and resource recovery in wastewater treatment. J. Ind. Ecol. 2018, 22, 1127-1138. [CrossRef]

9. Diaz-Elsayed, N.; Rezaei, N.; Guo, T.; Mohebbi, S.; Zhang, Q. Wastewater-based resource recovery technologies across scale: A review. Resour. Conserv. Recycl. 2019, 145, 94-112. [CrossRef]

10. Butler, B. Struvite or Traditional Chemical Phosphorus Precipitation-What Option Rocks? Australian Meat Processor Corporation: Sydney, Australia, 2018.

11. Álvarez-de Prado, L.; de Simón-Martín, M.; Diez-Suárez, A.-M.; Blanes-Peiró, J.; González-Martínez, A. Optimal sizing and location of co-digestion power plants in Spain through a GIS-based approach. Environments 2018, 5, 137. [CrossRef]

12. Brunner, C.; Muster, B. Membrane Distillation, a Thermally Driven Separation Water Treatment Technology. AEE INTEC. 2018. Available online: https:/ / www.slideshare.net/sustenergy/membrane-distillation-a-thermally-driven-separation-watertreatment-technology (accessed on 27 June 2020).

13. Morelli, B.; Cashman, S.; Ma, X.C.; Garland, J.; Turgeon, J.; Fillmore, L.; Bless, D.; Nye, M. Effect of nutrient removal and resource recovery on life cycle cost and environmental impacts of a small scale water resource recovery facility. Sustainability 2018, 10, 3546. [CrossRef]

14. Naidu, G.; Tijing, L.; Johir, M.A.H.; Shon, H.; Vigneswaran, S. Hybrid membrane distillation: Resource, nutrient and energy recovery. J. Membr. Sci. 2020, 599, 117832. [CrossRef]

15. Liao, B.-Q.; Kraemer, J.T.; Bagley, D.M. Anaerobic membrane bioreactors: Applications and research directions. Crit. Rev. Environ. Sci. Technol. 2006, 36, 489-530. [CrossRef]

16. Boghani, H.; Kim, J.R.; Dinsdale, R.M.; Guwy, A.J.; Premier, G.C. Reducing the burden of food processing washdown wastewaters using microbial fuel cells. Biochem. Eng. J. 2017, 117, 210-217. [CrossRef]

17. Dong, Y.; Qu, Y.; He, W.; Du, Y.; Liu, J.; Han, X.; Feng, Y. A 90-liter stackable baffled microbial fuel cell for brewery wastewater treatment based on energy self-sufficient mode. Bioresour. Technol. 2015, 195, 66-72. [CrossRef]

18. Chang, F.C.; Ko, C.H.; Wu, J.Y.; Wang, H.P.; Chen, W.S. Resource recovery of organic sludge as refuse derived fuel by fry-drying process. Bioresour. Technol. 2013, 141, 240-244. [CrossRef] [PubMed] 
19. Oluleye, G.; Jiang, N.; Smith, R.; Jobson, M. A novel screening framework for waste heat utilization technologies. Energy 2017, 125, 367-381. [CrossRef]

20. Bühler, F.; Holm, F.M.; Huang, B.; Andreasen, J.G.; Elmegaard, B. Mapping of low temperature heat sources in Denmark. In Proceedings of the ECOS 2015: 28th International Conference on Efficiency Cost, Optimization, Simulation and Environmental Impact of Energy Systems, Pau, France, 29 June-3 July 2015.

21. Memsys Water Technologies GmbH. Case Study of Memsys Pilot Plant to Concentrate High TDS/COD Wastewater (for ZLD) from Coal-To-Chemical (CTX) Industry in China. Available online: https:/ /www.memsys.eu/files/markets/oil-gas/memsyscase-study-ctx-china-01.pdf (accessed on 2 June 2020).

22. CCI BioEnergy. "Sugarqube" @ Toggam farm $55 \mathrm{~m}^{2}$-Quickqube with a 9kw CHP. 2016. Available online: https://www. ccibioenergy.com/wp-content/uploads/2018/01/case-study_sugarcube-_WEB.pdf (accessed on 26 June 2020).

23. Meena, R.A.A.; Yukesh Kannah, R.; Sindhu, J.; Ragavi, J.; Kumar, G.; Gunasekaran, M.; Rajesh Banu, J. Trends and resource recovery in biological wastewater treatment system. Bioresour. Technol. Rep. 2019, 7, 100235. [CrossRef]

24. Muhammad, Y.; Lee, W. Zero-liquid discharge (ZLD) technology for resource recovery from wastewater: A review. Sci. Total Environ. 2019, 681, 551-563. [CrossRef]

25. Lab, S. Scimago Journal \& Country Rank. Available online: https:/ / www.scimagojr.com/ (accessed on 9 March 2021).

26. Durham, R.J.; Hourigan, J.A. Waste management and co-product recovery in dairy processing. In Handbook of Waste Management and Co-Product Recovery in Food Processing; ScienceDirect: Amsterdam, The Netherlands, 2007; pp. 332-387.

27. Chen, G.Q.; Talebi, S.; Gras, S.L.; Weeks, M.; Kentish, S.E. A review of salty waste stream management in the Australian dairy industry. J. Environ. Manag. 2018, 224, 406-413. [CrossRef]

28. Pype, M.-L.; Walduck, K.; Goebel, B.; Jensen, P. Investigating Water and Wastewater Reuse and Recycling Opportunities: Identification and Segregation of Various Waste Streams; Australian Meat Processor Corporation: Sydney, Australia, 2017.

29. Wang, L.K.; Hung, Y.-T.; Lo, H.H.; Yapijakis, C. Waste Treatment in the Food Processing Industry; Taylor and Francis: Abingdon, UK, 2006.

30. El-Abbassi, A.; Hafidi, A.; Khayet, M.; García-Payo, M.C. Integrated direct contact membrane distillation for olive mill wastewater treatment. Desalination 2013, 323, 31-38. [CrossRef]

31. Jensen, P.; Batstone, D.J. NGERS and Wastewater Management-Mapping Waste Streams and Quantifying the Impacts; Meat and Livestock Australia: Sydney, Australia, 2013.

32. Reed, R. Waste handling in the brewing industry. In Brewing; ScienceDirect: Amsterdam, The Netherlands, 2006 ; pp. 335-357.

33. Jensen, P. Integrated Agri-Industrial Wastewater Treatment and Nutrient Recovery, Year 3; Australian Meat Processor Corporation: Sydney, Australia, 2015.

34. Muthukumaran, S.; Baskaran, K. Organic and nutrient reduction in a fish processing facility-A case study. Int. Biodeterior. Biodegrad. 2013, 85, 563-570. [CrossRef]

35. El-Abbassi, A.; Hafidi, A.; García-Payo, M.C.; Khayet, M. Concentration of olive mill wastewater by membrane distillation for polyphenols recovery. Desalination 2009, 245, 670-674. [CrossRef]

36. Dehghani, M.J.; Kyoo Yoo, C. Modeling and extensive analysis of the energy and economics of cooling, heat, and power trigeneration (CCHP) from textile wastewater for industrial low-grade heat recovery. Energy Convers. Manag. 2020, $205,112451$. [CrossRef]

37. City West Water. Approved Acceptance Criteria for Discharge to the Sewerage System; City West Water: Melbourne, Australia, 2017.

38. Hsien, C.; Low, J.S.C.; Chung, S.Y.; Tan, D.Z.L. Quality-based water and wastewater classification for waste-to-resource matching. Resour. Conserv. Recycl. 2019, 151, 104477. [CrossRef]

39. Low, J.S.C.; Tjandra, T.B.; Yunus, F.; Chung, S.Y.; Tan, D.Z.L.; Raabe, B.; Ting, N.Y.; Yeo, Z.; Bressan, S.; Ramakrishna, S.; et al. A collaboration platform for enabling industrial symbiosis: Application of the database engine for waste-to-resource matching. Procedia CIRP 2018, 69, 849-854. [CrossRef]

40. Kurup, G.G.; Adhikari, B.; Zisu, B. Treatment performance and recovery of organic components from high pH dairy wastewater using low-cost inorganic ferric chloride precipitant. J. Water Process. Eng. 2019, 32, 100908. [CrossRef]

41. Kurup, G.G.; Adhikari, B.; Zisu, B. Recovery of proteins and lipids from dairy wastewater using food grade sodium lignosulphonate. Water Resour. Ind. 2019, 22, 100114. [CrossRef]

42. Smithers, G.W. Whey and whey proteins-From 'gutter-to-gold'. Int. Dairy J. 2008, 18, 695-704. [CrossRef]

43. Song, Y.H.; Qiu, G.L.; Yuan, P.; Cui, X.Y.; Peng, J.F.; Zeng, P.; Duan, L.; Xiang, L.C.; Qian, F. Nutrients removal and recovery from anaerobically digested swine wastewater by struvite crystallization without chemical additions. J. Hazard. Mater. 2011, 190, 140-149. [CrossRef]

44. Montefrio, M.J.; Xinwen, T.; Obbard, J.P. Recovery and pre-treatment of fats, oil and grease from grease interceptors for biodiesel production. Appl. Energy 2010, 87, 3155-3161. [CrossRef]

45. Tran, N.N.; Tišma, M.; Budžaki, S.; McMurchie, E.J.; Gonzalez, O.M.M.; Hessel, V.; Ngothai, Y. Scale-up and economic analysis of biodiesel production from recycled grease trap waste. Appl. Energy 2018, 229, 142-150. [CrossRef]

46. Trentini, C.P.; Postaue, N.; Cardozo-Filho, L.; Reis, R.R.; Sampaio, S.C.; da Silva, C. Production of esters from grease trap waste lipids under supercritical conditions: Effect of water addition on ethanol. J. Supercrit. Fluids 2019, 147, 9-16. [CrossRef]

47. Romdhana, M.H.; Hamasaiid, A.; Ladevie, B.; Lecomte, D. Energy valorization of industrial biomass: Using a batch frying process for sewage sludge. Bioresour. Technol. 2009, 100, 3740-3744. [CrossRef] 
48. Wu, Z.; Zhang, J.; Li, Z.; Xie, J.; Mujumdar, A.S. Production of a solid fuel using sewage sludge and spent cooking oil by immersion frying. J. Hazard. Mater. 2012, 243, 357-363. [CrossRef] [PubMed]

49. Causer, T.P. Why Hasn't Torrefaction Taken Off. Available online: http://biomassmagazine.com/articles/16329/whyhasnundefinedt-torrefaction-taken-off (accessed on 31 May 2020).

50. Do, T.X.; Lim, Y.-I.; Cho, H.; Shim, J.; Yoo, J.; Rho, K.; Choi, S.-G.; Park, B.-Y. Process modeling and energy consumption of fry-drying and torrefaction of organic solid waste. Dry. Technol. 2016, 35, 754-765. [CrossRef]

51. Xie, M.; Nghiem, L.D.; Price, W.E.; Elimelech, M. A forward osmosis-membrane distillation hybrid process for direct sewer mining: System performance and limitations. Environ. Sci. Technol. 2013, 47, 13486-13493. [CrossRef] [PubMed]

52. Hancock, N.T.; Cath, T.Y. Solute coupled diffusion in osmotically driven membrane processes. Envrion. Sci. Technol. 2009, 43, 6769-6775. [CrossRef]

53. Nguyen, N.C.; Chen, S.S.; Nguyen, H.T.; Ray, S.S.; Ngo, H.H.; Guo, W.; Lin, P.H. Innovative sponge-based moving bed-osmotic membrane bioreactor hybrid system using a new class of draw solution for municipal wastewater treatment. Water Res. 2016, 91, 305-313. [CrossRef] [PubMed]

54. Kim, Y.; Li, S.; Francis, L.; Li, Z.; Linares, R.V.; Alsaadi, A.S.; Abu-Ghdaib, M.; Son, H.S.; Amy, G.; Ghaffour, N. Osmotically and thermally isolated forward osmosis-membrane distillation (FO-MD) integrated module. Environ. Sci. Technol. 2019, 53, 3488-3498. [CrossRef]

55. Haupt, A.; Lerch, A. Forward osmosis treatment of effluents from dairy and automobile industry-Results from short-term experiments to show general applicability. Water Sci. Technol. 2018, 78, 467-475. [CrossRef]

56. He, L.; Wang, Y.; Zhou, T.; Zhao, Y. Enhanced ammonia resource recovery from wastewater using a novel flat sheet gas-permeable membrane. Chem. Eng. J. 2020, 400, 125338. [CrossRef]

57. Drioli, E.; Wu, Y.; Calabrò, V. Membrane distillation in the treatment of aqueous solutions. J. Membr. Sci. 1987, 33, 277-284. [CrossRef]

58. Kiss, A.A.; Kattan Readi, O.M. An industrial perspective on membrane distillation processes. J. Chem. Technol. Biotechnol. 2018, 93, 2047-2055. [CrossRef]

59. Qiu, B.; Fan, S.; Tang, X.; Qi, B.; Deng, L.; Wang, W.; Liu, J.; Wang, Y.; Xiao, Z. Simultaneous recovery of phosphorus and nitrogen from liquid digestate by vacuum membrane distillation with permeate fractional condensation. Chin. J. Chem. Eng. 2020, 28, 1558-1565. [CrossRef]

60. Liu, C.; Chen, L.; Zhu, L. Application of membrane distillation for the treatment of anaerobic membrane bioreactor effluent: An especial attention to the operating conditions. Chemosphere 2018, 208, 530-540. [CrossRef]

61. Yao, M.; Woo, Y.C.; Ren, J.; Tijing, L.D.; Choi, J.S.; Kim, S.H.; Shon, H.K. Volatile fatty acids and biogas recovery using thermophilic anaerobic membrane distillation bioreactor for wastewater reclamation. J. Environ. Manag. 2019, 231, 833-842. [CrossRef]

62. Memsys Water Technologies GmbH. FAQ—Frequently Asked Questions; Memsys Water Technologies GmbH: Schwabmünchen, Germany, 2017.

63. Lin, S.; Nejati, S.; Boo, C.; Hu, Y.; Osuji, C.O.; Elimelech, M. Omniphobic membrane for robust membrane distillation. Environ. Sci. Technol. Lett. 2014, 1, 443-447. [CrossRef]

64. Guillen-Burrieza, E.; Ruiz-Aguirre, A.; Zaragoza, G.; Arafat, H.A. Membrane fouling and cleaning in long term plant-scale membrane distillation operations. J. Membr. Sci. 2014, 468, 360-372. [CrossRef]

65. Zhao, J.; Li, Y.; Pan, S.; Tu, Q.; Zhu, H. Performance of a forward osmotic membrane bioreactor for anaerobic digestion of waste sludge with increasing solid concentration. J. Environ. Manag. 2019, 246, 239-246. [CrossRef] [PubMed]

66. Du, X.; Shi, Y.; Jegatheesan, V.; Haq, I.U. A review on the mechanism, impacts and control methods of membrane fouling in mbr system. Membranes 2020, 10, 24. [CrossRef] [PubMed]

67. Xie, M.; Nghiem, L.D.; Price, W.E.; Elimelech, M. Toward resource recovery from wastewater: Extraction of phosphorus from digested sludge using a hybrid forward osmosis-membrane distillation process. Environ. Sci. Technol. Lett. 2014, 1, 191-195. [CrossRef]

68. Hakimi, M.H.; Jegatheesan, V.; Navaratna, D. The potential of adopting struvite precipitation as a strategy for the removal of nutrients from pre-anmbr treated abattoir wastewater. J. Environ. Manag. 2020, 259, 109783. [CrossRef]

69. Korchef, A.; Saidou, H.; Ben Amor, M. Phosphate recovery through struvite precipitation by co2 removal: Effect of magnesium, phosphate and ammonium concentrations. J. Hazard. Mater. 2011, 186, 602-613. [CrossRef]

70. Wu, S.; Zou, S.; Liang, G.; Qian, G.; He, Z. Enhancing recovery of magnesium as struvite from landfill leachate by pretreatment of calcium with simultaneous reduction of liquid volume via forward osmosis. Sci. Total Environ. 2018, 610-611, 137-146. [CrossRef] [PubMed]

71. Pacal, M.; Semerci, N.; Calli, B. Treatment of synthetic wastewater and cheese whey by the anaerobic dynamic membrane bioreactor. Environ. Sci. Pollut. Res. Int. 2019, 26, 32942-32956. [CrossRef] [PubMed]

72. Choi, J.-H.; Dockko, S.; Fukushi, K.; Yamamoto, K. A novel application of a submerged nanofiltration membrane bioreactor (nf $\mathrm{mbr}$ ) for wastewater treatment. Desalination 2002, 146, 413-420. [CrossRef]

73. Phattaranawik, J.; Fane, A.G.; Pasquier, A.C.S.; Bing, W.; Wong, F.S. Experimental study and design of a submerged membrane distillation bioreactor. Chem. Eng. Technol. 2009, 32, 38-44. [CrossRef]

74. Kim, H.C.; Shin, J.; Won, S.; Lee, J.Y.; Maeng, S.K.; Song, K.G. Membrane distillation combined with an anaerobic moving bed biofilm reactor for treating municipal wastewater. Water Res. 2015, 71, 97-106. [CrossRef] [PubMed] 
75. Song, X.; Luo, W.; Hai, F.I.; Price, W.E.; Guo, W.; Ngo, H.H.; Nghiem, L.D. Resource recovery from wastewater by anaerobic membrane bioreactors: Opportunities and challenges. Bioresour. Technol. 2018, 270, 669-677. [CrossRef] [PubMed]

76. Ogejo, J.A.; Li, L. Enhancing biomethane production from flush dairy manure with turkey processing wastewater. Appl. Energy 2010, 87, 3171-3177. [CrossRef]

77. Padi, R.K.; Chimphango, A. Commercial viability of integrated waste treatment in cassava starch industries for targeted resource recoveries. J. Clean. Prod. 2020, 265, 121619. [CrossRef]

78. Ziels, R.M.; Karlsson, A.; Beck, D.A.C.; Ejlertsson, J.; Yekta, S.S.; Bjorn, A.; Stensel, H.D.; Svensson, B.H. Microbial community adaptation influences long-chain fatty acid conversion during anaerobic codigestion of fats, oils, and grease with municipal sludge. Water Res. 2016, 103, 372-382. [CrossRef]

79. Tomaszewska, M.; Białończyk, L. Ethanol production from whey in a bioreactor coupled with direct contact membrane distillation. Catal. Today 2016, 268, 156-163. [CrossRef]

80. Lin, H.J.; Xie, K.; Mahendran, B.; Bagley, D.M.; Leung, K.T.; Liss, S.N.; Liao, B.Q. Sludge properties and their effects on membrane fouling in submerged anaerobic membrane bioreactors (SANMBRs). Water Res. 2009, 43, 3827-3837. [CrossRef]

81. Gao, D.-W.; Hu, Q.; Yao, C.; Ren, N.-Q.; Wu, W.-M. Integrated anaerobic fluidized-bed membrane bioreactor for domestic wastewater treatment. Chem. Eng. J. 2014, 240, 362-368. [CrossRef]

82. Johir, M.A.H.; George, J.; Vigneswaran, S.; Kandasamy, J.; Grasmick, A. Removal and recovery of nutrients by ion exchange from high rate membrane bio-reactor (MBR) effluent. Desalination 2011, 275, 197-202. [CrossRef]

83. Mullen, P.; Venkiteshwaran, K.; Zitomer, D.H.; Mayer, B.K. Ion exchange nutrient recovery from anaerobic membrane bioreactor permeate. Water Environ. Res. 2019, 91, 606-615. [CrossRef]

84. Zhou, X.; Cui, P.; Wang, X.; He, L. Thermal investigations into an organic rankine cycle (ORC) system utilizing low grade waste heat sources. Procedia Eng. 2017, 205, 4142-4148. [CrossRef] 